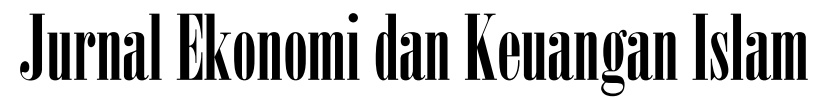

Available at https://journal.uii.ac.id/jeki

\section{Branchless banking and profitability in the Indonesian Islamic banking industry}

\author{
Mohammad Nur Rianto Al Arif ${ }^{1}$, Uut Tri Cahyani² \\ ${ }^{1}$ Universitas Islam Negeri (UIN) Syarif Hidayatullah, Jakarta, Indonesia \\ ${ }^{2}$ Universitas Muhammadiyah Prof. DR. HAMKA, Jakarta, Indonesia
}

\section{Article History \\ Received : 30 May 2021 \\ Revised : 22 June 2021 \\ Accepted : 23 June 2021 \\ Published : 1 July 2021}

\section{Keywords:}

branchless banking, profitability, Islamic banking.

\section{DOI:}

https://doi.org/10.20885/JEKI.vol7.is s2.art4

JEL Clasification:

G21, G29

Corresponding author:

nur.rianto@uinjkt.ac.id

Author's email:
uuttricahyani@gmail.com

Paper type:

Research paper

Cite this article:

Al Arif, M. N. R., \& Cahyani, U. T. (2021). Branchless banking and profitability in the Indonesian Islamic banking industry. Jurnal Ekonomi dan Kenangan Islam, 7(2), 154-160. https://doi.org/10.20885/JEKI.vol7.is s2.art4

\begin{abstract}
Purpose - This study aims to examine the effect of branchless banking on the level of profitability in Islamic banks.
\end{abstract}

Methodology - This study uses two Islamic banks that have implemented branchless banking (BRI Syariah and BTPN Syariah) and two Islamic banks that have not implemented this policy (BNI Syariah and Bukopin Syariah). This study uses regression analysis techniques with panel data. The model used in this study is the fixed effect model.

Findings - This study shows that the branchless banking policy has a positive impact on profitability. This result implies that the implementation of branchless banking can improve the performance of Islamic banks in Indonesia. So, it is hoped that other Islamic banks can implement this branchless banking policy to overcome the limitations of their network. In addition, branchless banking can expand customer reach to areas that have not been served well by Islamic banks.

Originality - Research on branchless banking in Islamic banks in Indonesia is still limited. There are only few studies comparing banks that have implemented branchless banking with banks that have not implemented this policy. Therefore, this research will contribute to a study that discusses branchless banking in Islamic banks in Indonesia, especially its impact on performance.

\section{Introduction}

The growth of Financial Inclusion in Indonesia in 2019 increased significantly. Based on the 2019 National Financial Literacy Survey results, the financial inclusion index reached $76.19 \%$ and the financial literacy index was $38.03 \%$ (OJK, 2019). This data shows that only 76 out of 100 Indonesians are connected to formal financial services. Meanwhile, 38 people have a good understanding of financial products. Two exciting things are inscribed from the results of this survey. First, the figure exceeds the target set by the government. Presidential Regulation (Perpres) No. 82/2016 concerning the National Strategy for Financial Inclusion, states that the financial inclusion target in 2019 is $75 \%$. Second, there was a reasonably high and balanced spike 
compared to the survey results three years ago. An increase of about $8 \%$ for each index indicates that the push to expand access and financial education has been carried out proportionally.

In order to increase financial inclusion in Indonesia, the Financial Services Authority $(\mathrm{OJK})$ cooperates with Bank Indonesia (BI) by implementing programs, namely Digital Financial Services (LKD) and Laku Pandai (otherwise known as branchless banking). Branchless banking has been effective since issuing the Financial Services Authority Regulation (POJK) No.19/POJK.03/2014. Branchless banking is intended for people who have not been touched by banking. Using branchless banking, people can conduct formal financial service transactions without having to come to the bank. As a result, financial inclusion plays a significant role in driving away poverty from the country (Iqbal \& Sami, 2017).

Branchless Banking is a revolutionary concept that will change the behavior map of the Indonesian people in dealing with banking. With the presence of branchless banking, people can enjoy various banking services through bank agents. The utilization of information technology is a significant factor in the implementation of branchless banking. In the branchless banking ecosystem, agents hold a vital role because they are the spearhead when customers do banking transactions (Yuliaty \& Lubis, 2017).

Branchless banking is one solution to cover the weaknesses of Islamic banks. Rusydiana (2016) mentions that network limitation is one of Indonesia's weaknesses in the Islamic banking industry. Branchless banking can be a strategic decision in expanding the network with minimum costs because the expansion of the office network is not always linear with the increase in the performance of the banking industry (Prasetyo \& Sunaryo, 2015). Therefore, branchless banking is a suitable model to increase market share (Yudiana, 2018).

One of the objectives of branchless banking is to reduce the costs that the bank will incur. In opening a bank branch office, an initial investment of Rp 500 million up to Rp 1 billion is required, depending on the branch model and market segment to be served. Then the operational costs can reach Rp 50 million up to Rp 100 million per month. Junarti et al. (2017) found that the expansion of Islamic banking with low cost is the highest rating of branchless banking policy. Thus, branchless banking is expected to reduce operational costs and increase bank profitability. Branchless banking is believed to have the potential to reduce costs and improve branchless banking services, to expand the reach of new markets, namely people whom banks have not previously served, thereby improving bank's profitability (Sarah, 2015; Putri \& Yusuf, 2017).

Research on the application of branchless banking in Islamic banks is still limited, so that this research will make a significant contribution to the study of branchless banking in Islamic banks. In addition, no research has been found that compares banks that have implemented branchless banking with those that have not. This technique is one of the contributions in this research. Therefore, this study aims to examine whether branchless banking policies can affect the level of profitability in Islamic banks.

\section{Literature Review}

Branchless banking is one of the policies adopted to increase financial inclusion (Tandika \& Sevriana, 2017). Financial inclusion can be defined as the access to formal financial services at an affordable cost for all members of an economy by technology (Diniz et al., 2012; Santoso \& Ahmad, 2016). Branchless banking will be tremendous potential in the development of financial services to individuals who do not have access to the bank's branch office network (Dzombo et al., 2017). In addition, branchless banking will make it easier for banks to reach a wider community, both geographically and expand the unbanked segment of society (Purwati et al., 2014). The use of branchless banking is based on the location factor near the residence and the ease of accessing it (Rachmawati et al., 2019).

The objectives of this policy are: first, to provide financial products that are simple and easily understood by the unbanked. Second, expanding the banking network through communities widely developed in society (Junarti et al., 2017). Third, the main segment of branchless banking is poor and unbanked (low-income people) because traditional banks (having 
branches and physical infrastructure) consider them quite costly to provide banking services and products (Yudiana, 2018). In this case, information technology becomes the positioning and key differentiator of branchless banking.

According to Mas (2009), there are three models of branchless banking. The first model is run by a mobile network operator called $\mathrm{MNO}$ and is characterized by a strong distribution channel and many customers who are generally unacquainted with banks. The second model is a bank-led model that is created based on the principle of the banking institution. Banks are licensed and supervised by the central bank. A third party manages the third case of the BB model. This model can help ensure balanced cooperation and viable partnership mong banks, telecommunications companies, and other member partners.

Branchless banking can affect improving the performance of banks, such as increasing savings funds (Putri \& Yusuf, 2017; Al Arif \& Firmansyah, 2018), profitability (Sarah, 2015; Putri \& Yusuf, 2017), as well as efficiency (Yuliaty \& Lubis, 2017). In addition, branchless banking positively impacted economic growth in a region (Afandi, 2021). However, several other studies show that branchless banking did not affect banking performance in Indonesia (Kustina \& Sugiarto, 2020). There are several things that cause the ineffectiveness of this branchless banking policy in improving bank's performance. First, there is still minimal socialization to the public regarding branchless banking. Second, the fluctuating number of branchless banking agents. Third, the agent's ability to explain bank services is still low (Kustina \& Sugiarto, 2020).

\section{Research Methods}

The objects in this study include four full-fledged Islamic banks, namely two Islamic banks that have implemented branchless banking (BRI Syariah and BTPN Syariah) and two Islamic banks that have not implemented branchless banking (BNI Syariah and Bukopin Syariah). The financial statements used are from the first quarter of 2015 to the first quarter of 2020.

The analysis technique used is panel regression with dummy variables. This study makes a distinction between banks that have implemented branchless banking and those that have not. The mathematical equations used in this study are:

$$
\text { ROAit }=\alpha+\beta_{1} \mathrm{D}_{-} \mathrm{BB}_{\text {it }}+\beta_{2} \mathrm{BOPO}_{\mathrm{it}}+\beta_{3} \mathrm{FDR}_{\mathrm{it}}+\beta_{4} \mathrm{CAR}_{\mathrm{it}}+\beta_{5} \mathrm{DPK}_{\mathrm{it}}+\mathrm{e}
$$

Where:

$\mathrm{ROA}_{\mathrm{it}}$ : return on asset

${\mathrm{D} \_B B_{i t}}_{\text {it }}$ : dummy for branchless banking

Where : $0=$ Non branchless banking; $1=$ branchless banking

$\mathrm{BOPO}_{\text {it }}$ : operational efficiency of Islamic banks

$\mathrm{FDR}_{\text {it }} \quad$ : financing to deposit ratio

$\mathrm{CAR}_{\mathrm{it}} \quad$ : capital adequacy ratio

$\mathrm{DPK}_{\text {it }} \quad$ : deposit funds

This research can use one of the following three models: the common effect model, the fixed-effect model, and the random effect model. In order to find the right model to be used in this study, the Chow test and Hausman test will be carried out. Chow test is used to test the best model among common effect models or fixed-effect models. At the same time, the Hausman test was conducted to test the best model between the fixed effect model and the random effect model. The results of the tests carried out show that the model used in this study is the fixed effect model.

\section{Result and Discussion}

The initial test carried out is the Chow test. This test aims to test the best model between the common effect model and the fixed effect model. Based on the results of the Chow test in Table 1 , the $\mathrm{F}$ statistic value is 3.247. This statistical $\mathrm{F}$ value is greater than the F-table value (3.07). Based on these results, Ho is rejected, so the best model is the fixed effect model. 
Table 1. Chow Test Result

\begin{tabular}{lccc}
\hline Effects Test & Statistic & d.f. & Prob. \\
\hline Period F & 3.247721 & $(20,58)$ & 0.0002 \\
Period Chi-square & 63.115144 & 20 & 0.0000 \\
\hline
\end{tabular}

The next test is the Hausman test, and this test is to test the best model between the fixed effect model and the random effect model. Table 2 shows the Hausman test value of 62,460 . This value is greater than the chi-square value. This result shows that the best model is the fixed effect model. Therefore, based on the Chow test and Hausman test results, the best model in this study is the fixed effect model.

Table 2. Hausman Test Result

\begin{tabular}{cccc}
\hline Test Summary & Chi-Sq. Statistic & Chi-Sq. d.f. & Prob. \\
\hline Period random & 62.460462 & 5 & 0.0000 \\
\hline
\end{tabular}

Table 3 shows differences in profitability between banks that have implemented branchless banking and those that have not. Again, a positive sign indicates that banks that have implemented branchless banking have a better level of profitability than banks that have not implemented branchless banking. This result is consistent with several previous studies which showed the impact of branchless banking on increasing profitability (Sarah, 2015; Putri \& Yusuf, 2017; Hidayanti et al., 2021).

Table 3. Empirical Result

\begin{tabular}{cccc}
\hline Variable & Coefficient & Std. Error & t-statistics \\
\hline C & 32.56034 & 4.278166 & 7.610816 \\
Dummy-BB & 1.580445 & 0.199538 & 7.920501 \\
BOPO & -0.291829 & 0.011057 & -26.39427 \\
FDR & 0.095968 & 0.016417 & 5.845570 \\
CAR & 0.003059 & 0.023187 & 0.131938 \\
Ln_DPK & 0.829566 & 0.142110 & 5.837491 \\
\hline R-squared & 0.985858 & F-statistics & 161.7267 \\
Adj R-squared & 0.979762 & Prob (F-Statistics) & 0.000000 \\
\hline
\end{tabular}

While the control variables indicate that the level of operational efficiency, liquidity ratios, and deposit funds impact the level of profitability, the capital adequacy ratio has no impact on profitability. The negative sign on the $\mathrm{BOPO}$ variable indicates that the more efficient a bank is, the higher its profitability. Likewise, the liquidity ratio (FDR) indicates that the more liquid a bank is, the higher the level of profitability will be. Likewise with deposit funds, where increasing deposit funds will be able to produce higher levels of profitability.

Table. 4. Return on Asset

\begin{tabular}{cccccc}
\hline ROA & $\mathbf{2 0 1 5}$ & $\mathbf{2 0 1 6}$ & $\mathbf{2 0 1 7}$ & $\mathbf{2 0 1 8}$ & $\mathbf{2 0 1 9}$ \\
\hline BRIS & 0.77 & 0.95 & 0.51 & 0.43 & 0.31 \\
BTPNS & 5.20 & 9.00 & 11.20 & 12.40 & 13.60 \\
BNIS & 1.43 & 1.44 & 1.31 & 1.42 & 1.82 \\
BSB & 0.79 & $(1.12)$ & 0.02 & 0.02 & 0.04 \\
\hline
\end{tabular}

Table 4 shows the development of the profitability level of the four banks that are the object of this research. BTPN Syariah is a bank that focuses on implementing branchless banking, shows an increasing level of profitability. Meanwhile, the level of profitability from BRI Syariah is still fluctuating. However, based on Table 4, generally shows that branchless banking can enhance bank's performance. 
In addition to affecting profitability, branchless banking also affects increasing deposit funds. Al Arif and Firmansyah (2018) show differences in deposit funds between before and after the implementation of branchless banking at BRI Syariah. Adzkia (2014) found the same thing at BJB Syariah. This result shows that branchless banking can expand the banking network to unbanked people (Nagendra \& Shenoy, 2011).

In developing branchless banking, Islamic banking must cooperate with local economic units. Therefore, Islamic banking must be able to develop financial product innovations that follow each region's characteristics and needs. In addition, the mastery of qualified information technology from each agent is an essential key in developing branchless banking (Yudiana, 2018). Security and trust factors determine people's access to branchless banking services (Chege \& Njeru, 2016; Maina \& Mwangi, 2017). The level of public trust in using branchless banking is determined by service quality, system quality, reputation, and perceived credibility (Chaudhry \& Parveiz, 2016). The reliability of infrastructure technology is also a key factor for a successful branchless banking program (Shabirah \& Aldianto, 2014; Zaffar et al., 2020).

In the current covid-19 condition, branchless banking will help the community remain served by financial services (Shahabi et al., 2021). Inclusive financial services with agents are the main thing in promoting economic growth in a country (Mahmood \& Sarker, 2015). Branchless banking can have a positive impact on MSMEs in developing their business (Sarika, 2015). According to Junarti et al., (2017), several strategic issues are faced in optimizing branchless banking by Islamic banks. First, they should expand promotion and marketing to the entire community. Second, increase education and socialization to the community regarding the values and basic principles of Islamic banking. Third, improve the quality of agents through continuous training (Palaon et al., 2020). Fourth, focus on banking products and services that generate more revenues.

\section{Conclusion}

This study aims to see whether there are differences in profitability levels between banks that have implemented branchless banking and those that have not. Empirical results show that there are differences in profitability between these two types of banks. Furthermore, this result shows that the branchless banking policy can increase the range of banking services to increase bank's performance.

Islamic banks that want to implement branchless banking must strengthen technology because technology is essential in implementing branchless banking. Banks must make technology that is safe, easy, and convenient to use. Although this technology investment costs relatively high in the short term, the bank can operate at a minimum cost in the long term. In addition, banks need to train agents who are the spearhead in this branchless banking service to the public.

\section{Author Contribution}

Conceptualization: M. Nur Rianto Al Arif \& Uut Tri Cahyani

Data curation: Uut Tri Cahyani

Formal Analysis: M. Nur Rianto Al Arif \& Uut Tri Cahyani

Investigation: M. Nur Rianto Al Arif \& Uut Tri Cahyani

Methodology: M. Nur Rianto Al Arif \& Uut Tri Cahyani

Project Administration: Uut Tri Cahyani

Supervision: M. Nur Rianto Al Arif

Validation: M. Nur Rianto Al Arif \& Uut Tri Cahyani

Visualization: M. Nur Rianto Al Arif

Writing - original draft: M. Nur Rianto Al Arif \& Uut Tri Cahyani

Writing - review \& editing: M Nur Rianto Al Arif

\section{References}

Adzkia, M. F. (2014). Efektivitas program layanan jemput maslahah dalam meningkatkan dana pihak ketiga pada PT BJB Syariah cabang Padjadjaran Bogor. (Unpublished Thesis). UIN Syarif Hidayatullah Jakarta. 
Afandi, M. A. (2021). Contribution of Islamic commercial bank financing to East Java economic growth in the era of branchless banking. Journal of Economics Research and Social Sciences, 5(1), 1-12. https://doi.org/10.18196/jers s.v5i1.10926

Al Arif, M. N. R., \& Firmansyah. (2018). Laku Pandai's program and deposit funds: study at bank of BRI sharia. Jurnal Ekonomi, XXIII(1), 1-9. http://dx.doi.org/10.24912/je.v23i1.329

Chaudhry, A. A., \& Parveiz, A. (2016). Determinants of users' trust for branchless banking in Pakistan. Journal of Internet Banking and Commerce, 21, 141-150. Retrieved from https://www.icommercecentral.com/open-access/determinants-of-users-trust-forbranchless-banking-in-pakistan.pdf

Chege, K. D., \& Njeru, A. (2016). Influence of branchless banking services on saving practices in informal settlements of Kenya: A case study of Kibera. International Journal of Science and Research, 5(10), 1264-1273. Retrieved from https://www.ijsr.net/search_index_results_paperid.php?id=20101602

Diniz, E., Birochi, R., \& Pozzebon, M. (2012). Triggers and barriers to financial inclusion: The use of ICT-Based branchless banking in Amazon county. Electronic Commerce Research and Applications, 11, 484-494. https://doi.org/10.1016/j.elerap.2011.07.006

Dzombo, G. K., Kilika, J. M., \& Maingi, J. (2017). the effect of branchless banking strategy on the financial performance of commercial banks in Kenya. International Journal of Financial Research, 8(4), 167-170. https://doi.org/10.5430/ijfr.v8n4p167

Hidayanti, U., Pratiwi, L. N., \& Tamara, D. A. D. (2021). Analisis perbandingan kinerja keuangan sebelum dan setelah penerapan program branchless banking. Journal of Applied Islamic Economics and Finance, 1(2), 276-296. Retrieved from https://jurnal.polban.ac.id/ojs3.1.2/jaief/article/view/2465

Iqbal, B. A., \& Sami, S. (2017). Role of banks in financial inclusion in India. Contaduría y Administración, 62(2), 644-656. https://doi.org/10.1016/j.cya.2017.01.007.

Junarti., Anwar, S., \& Anisa, F. (2017). Optimization strategy of Laku Pandai policy in Islamic bank: A case study. Tarkia Islamic Finance and Business Review, 11(2), 127-144. https://doi.org/10.30993/tifbr.v11i2.140

Kustina, K. T., \& Sugiarto, Y. W. (2020). Pengaruh penerapan branchless banking dan E-Banking terhadap kinerja keuangan sektor perbankan di Indonesia. Jurnal Ilmiah Akuntansi dan Bisnis, 5(1), 116-128. https://doi.org/10.38043/jiab.v5i1.2428

Mahmood, R., \& Sarker, S. (2015). Inclusive growth through branchless banking: A review of agent banking and its impact. Journal of Economics and Sustainable Development, 6(23), 86-93. Retrieved from https://www.iiste.org/Journals/index.php/JEDS/article/view/27624

Maina, H. T. M., \& Mwangi, M. W. (2017). Factors influencing the uptake of agency banking services by customers in commercial bank in Kenya: A case of Kenya commercial bank. The Strategic Journal of Business and Change Management, 2(1), 177-197. Retrieved from http://strategicjournals.com/index.php/journal/article/view/26

Mas, I. (2009). The economics of branchless banking. Innovations, 2, 57-75. https://doi.org/10.1162/itgg.2009.4.2.57

Nagendra, S., \& Shenoy, N. (2011). Financial inclusion via branchless banking to extend the outreach-case study of corporation bank. International Journal of Advanced Research in Management and Technology, 1(1), 29-58.

Otoritas Jasa Keuangan [OJK]. (2019). Survei nasional literasi keuangan tahun 2019. Otoritas Jasa Keuangan. Retrieved from https://www.ojk.go.id/id/berita-dankegiatan/publikasi/Pages/Survei-Nasional-Literasi-dan-Inklusi-Keuangan-2019.aspx 
Prasetyo, H., \& Sunaryo, S. (2015). The branch expansion and the performance of the banks: The case of Indonesia. Bulletin Ekonomi Moneter dan Perbankan, 18(1), 85-106. https://doi.org/10.21098/bemp.v18i1.518.

Purwati, Y., Fransiska, R., \& Nugroho, P. I. (2014). Strategi peningkatan kemampuan adopsi teknologi branchless banking untuk memperluas inklusi keuangan di masyarakat pedesaan. Seminar Nasional dan Call for Paper UMS, 205. Retrieved from https://publikasiilmiah.ums.ac.id/handle/11617/4671.

Palaon, H., Wiryono, S. K., \& Faturohman, T. (2020). Branchless banking agents: Business satisfaction, continuity, and viability. Cogent Business and Management, 7(1), 1823585. https://doi.org/10.1080/23311975.2020.1823585.

Putri, A. H., \& Yusuf, M. (2017). Analisis dampak program laku pandai terhadap pertumbuhan dana pihak ketiga, pertumbuhan likuiditas dan pertumbuhan profitabilitas. Jurnal Magisma, 5(1), 1-8. https://doi.org/10.35829/magisma.v5i1.8.

Rachmawati, R., Farda, N. M., Rijanta., Setiyono, B., Hapsari, S. A., Ramadhan, E., \& Dharmawan, R. D. (2019). The comparison between the uses of branchless banking in urban and rural areas: Geographical perspective. IOP Conference Series: Earth and Environmental Science, 338, 012016. https://doi.org/10.1088/1755-1315/338/1/02/2016.

Rusydiana, A. S. (2016). Analisis masalah pengembangan perbankan syariah di indonesia: aplikasi metode analytic network process. Esensi: Jurnal Bisnis dan Manajemen, 6(2), 237-246. https://doi.org/ 10.15408/ess.v6i2.3573.

Santoso, B., \& Ahmad, K. (2016). Islamic microfinance branchless banking model in Indonesia. Intellectual Discourse, Special Issue, 409-433. Retrieved from https://journals.iium.edu.my/intdiscourse/index.php/id/article/view/927.

Sarah, H. (2015). Dampak branhcless banking terhadap kinerja keuangan PT. Bank Muamalat Indonesia Tbk. Jurnal Mu₹araah, 3(5), 136-157. https://doi.org/10.29244/jam.3.2.136-157.

Sarika, J. C. A (2015). A study of banking sector's initiatives towards financial inclusion in India. Journal of Commerce and Management Thought, 6(1), 55-77. https://doi.org/10.5958/0976478x.2015.00004.X

Shabirah, I., \& Aldianto, L. (2014). The suitable model of branchless banking implementation in Indonesia. Journal of Business and Management, 3(6), 633-645. Retrieved from http:/ / download.garuda.ristekdikti.go.id/article.php?article $=1529544 \& v a l=2218 \&$ title $=\mathrm{T}$ HE\%20SUITABLE\%20MODEL\%20OF\%20BRANCHLESS\%20BANKING\%20IMP LEMENTATION\%20IN\%20INDONESIA.

Shahabi, V., Azar, A., Razi, F. F., \& Shams, M. F. F. (2021). Simulation of the effect of Covid-19 outbreak on the development of branchless banking in Iran: Case study of Resalat Qardal-Hasan Bank. Review of Behavioral Finance, 13(1), 85-108. https://doi.org/10.1108/RBF06-2020-0123.

Tandika, D., \& Sevriana, L. (2017). Adopsi terhadap inovasi: kajian konseptual implementasi program Laku Pandai pada layanan BRILink. Performa: Jurnal Manajemen dan Bisnis, 14(1), 53-64. https://doi.org/ DOI:10.29313/PERFORMA.V0I1.2641.

Yudiana, F. E. (2018). Modifikasi branchless banking pada perbankan syariah di Indonesia berdasarkan kearifan lokal. Muqtasid, 9(1), 14-28. http://dx.doi.org/10.18326/muqtasid.v9i1.14-28.

Yuliaty, T., \& Lubis, A. N. (2017). Agen branchless banking untuk mencapai masyarakat bankable. Bisnis, 5(2), 305-322. http://dx.doi.org/10.21043/bisnis.v5i2.3016.

Zaffar, M. A., Kumar, R. L., \& Zhao, K. (2019). Using agent-based modelling to investigate diffusion of mobile, 117, 62-74. https://doi.org/10.1016/j.dss.2018.10.015. 